Evans, D. I. K. (1969). Paroxysmal nocturnal hemoglobinuria and leukaemia. Brit. med. J., 4, 300-301.

Hansen, N. E., and Killmann, S. A. (1970). Paroxysmal nocturnal hemoglobinuria in myelofibrosis. Blood, 36, 428-431.

Holden, D., and Lichtman, H. (1969). Paroxysmal nocturnal herr oglobinuria with acute leukemia. Blood, 33, 283-286.

Jenkins, D. E., Jr., and Hartmann, R. C. (1969). Paroxysmal nocturnal hemoglobinuria terminating in acute myeloblastic leukemia. Blood, 33, 274-282.

Jenkins, D. E., Jr., Hartmann, R. C., and Kerns, A. L. (1967). Serumred cell interactions at low ionic strength: Erythrocyte complement coating and hemolysis of paroxysmal nocturnal hemoglobinuria cells. J. clin. Invest., 46, 753-761.

Kaufmann, R. W., Schechter, G. P., and McFarland, W. (1969). Paroxysmal nocturnal hemoglobinuria terminating in acute granulocytic leukemia. Blood, 33, 287-291.

Lewis, S. M., and Dacie, J. V. (1967). The aplastic anaemiaparoxysmal nocturnal hemoglobinuria syndrome. Brit. $J$. Haemat., 13, 236-251.

Metz, J., Bradlow, B. A., Lewis, S. M., and Dacie, J. V. (1960). The acetylcholinesterase activity of the erythrocytes in paroxysmal nocturnal haemoglobinuria in relation to the severity of the disease. Brit. J. Haemat., 6, 372-380.

Michel, H. O. (1949). An electrometric method for the determination of red blood cell and plasma cholinesterase activity. J. Lab. clin. Med., 34, 1564-1568.

\section{Estimation of serum and urinary muramidase with the eel aggregom- eter}

\section{J. P. HAYES From the Department of Haematology, Westminster Medical School, London}

In view of recent interest in the assay of muramidase in biological fluids, especially in the diagnosis of the acute monocytic leukaemias, it became necessary to organize such a method in our department. The methods available depend on measuring the lysis of a suspension of the bacterium Micrococcuslysodeikticus either in an agar plate (Osserman and Lawlor, 1966) or by nephelometry in a spectrophotometer cuvette (Parry, Chandan, and Shahani, 1965; Gorin, Papapavlou, and Wang, 1971). An EEL 169 aggregation meter with an attached recorder appeared ideally suited for the latter technique. Accordingly the latter method was modified as follows to suit our requirements.

The substrate is a $50 \mathrm{mg} \%$ suspension of ultraviolet-killed and lyophylized M.Lysodeikticus in $\mathrm{M} / 15$ phosphate buffer as supplied by Difco. To $0.75 \mathrm{ml}$ of this suspension in a plastic disposable aggregometer cuvette is added $0.25 \mathrm{ml}$ of a $0.3 \mathrm{M}$ saline solution. This mixture is then brought to $37^{\circ} \mathrm{C}$ by incubation for $90 \mathrm{sec}$ on the heated block of the aggregometer. At the end of this period $0.5 \mathrm{ml}$ of serum or standard enzyme solution is added and the timer and stirrer are started, the output of the machine being passed to a Servoscribe recorder set at a sensitivity of $5 . \mathrm{mV}$ and with a chart speed of $600 \mathrm{~cm} / \mathrm{hr}$. Recording continues for five minutes.

A standard curve is constructed for each batch of tests using crystalline egg-white muramidase as obtained from BDH Pharmaceuticals with an activity of $25000 \mathrm{IU} / \mathrm{mg}$. A stock solution is made up containing $5 \mathrm{mg}$ in $100 \mathrm{ml}$ phosphate buffer which is then further diluted also with buffer to give $11 \mathrm{final}$ standards of $0 \cdot 5 \mu \mathrm{g} / \mathrm{ml} 1 \cdot 0,2 \cdot 0,3 \cdot 0,4 \cdot 0,5 \cdot 0,6 \cdot 0,7 \cdot 0$, $8 \cdot 0,9 \cdot 0$, and $10 \cdot 0$. Unknown samples are then run consecutively using $0.5 \mathrm{ml}$ neat serum or urine instead of the dilutions of standard enzyme.

Substrate suspensions and enzyme standards are made up the night before a run of tests which are at present carried out on one day per week. The standards lose about $40 \%$ of their activity after one week at $4{ }^{\circ} \mathrm{C}$. After one week at $4{ }^{\circ} \mathrm{C}$ the substrate suspensions have begun to putrefy and are no longer suitable for use.

Received for publication 18 November 1971. 


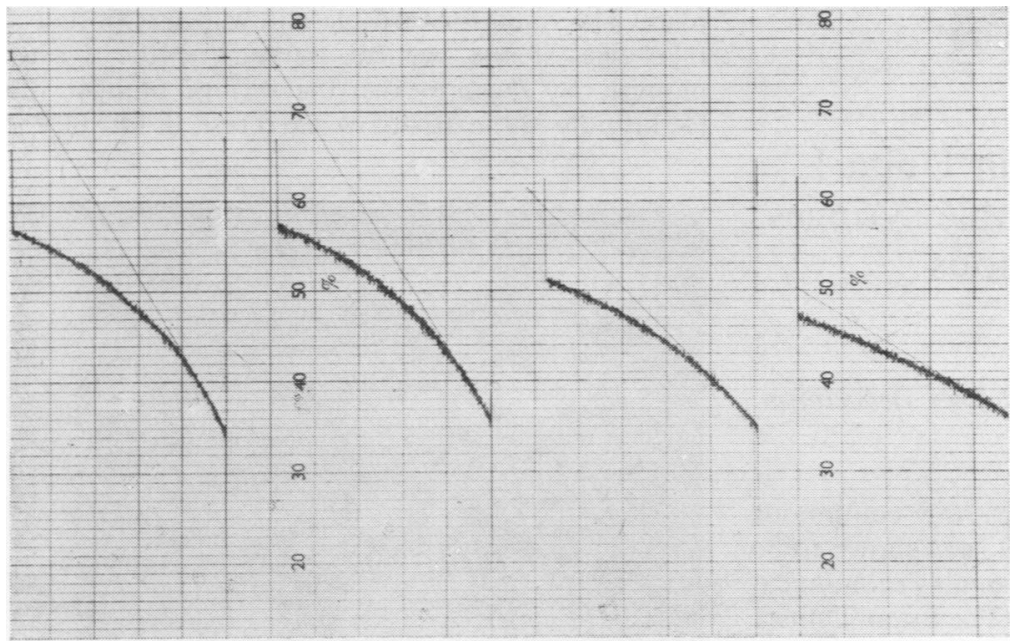

Fig. 1 A selection of tracings from a series of standard enzyme dilutions.

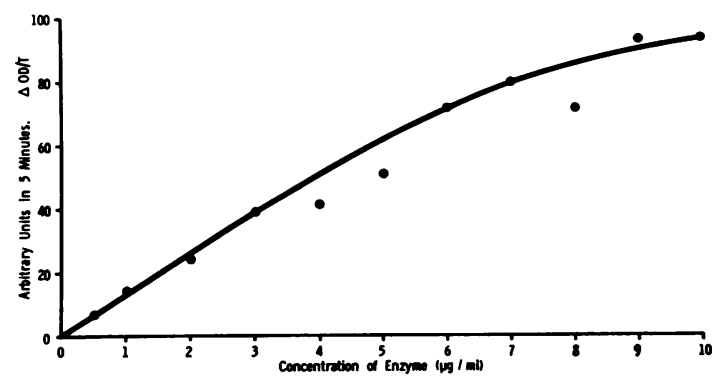

temperatures and the corresponding standard curve was employed.

The normal range obtained from 26 fresh sera was $3.7 \pm 2.0 \mu \mathrm{g} / \mathrm{ml}$ while in 35 normal blood bank sera stored for seven days at $4^{\circ} \mathrm{C}$ it was $3.4 \pm 2.5 \mu \mathrm{g} / \mathrm{ml}$. The difference is not significant. The normal urines we have assayed have contained no detectable muramidase. Sera from cases of myelomonocytic leukaemia have so far given results above $10 \mu \mathrm{g} / \mathrm{ml}$ but the numbers are not yet sufficient to give firm

Fig. 2 Enzyme dilution curve. conclusions.

The assays are carried out at $37^{\circ} \mathrm{C}$ instead of the more usual $25^{\circ} \mathrm{C}$ for enzyme assays because the former temperature is the aggregometer's thermostat setting for platelet aggregation tests. In our experience running the assays at this temperature produces a steeper standard curve with a consequent increase in precision. There was no significant difference in results when 11 stored sera were assayed at both

\section{References}

Gorin, G., Papapavlou, L., and Wang, S. F. (1971). Assay of lysozyme by its lytic action on M. lysodeikticus cells. Analyt. Biochem., 39, 113-127.

Osserman, E. F., and Lawlor, D. P. (1966). Serum and urinary lysozyme (muramidase) in monocytic and monomyelocytic leukemia. J. exp. Med., 124, 921-951.

Parry, R. M., Jr., Chandan, R. C., and Shahani, K. M. (1965). A rapid and sensitive assay of muramidase. Proc. Soc. exp. Biol. (N.Y.), 119, 384-386. 